\title{
Bacteriological Analysis of Ready-to-Eat Barbecue Meat (Suya) Sold in Yenagoa, Bayelsa State Nigeria
}

\author{
Nwachukwu Micheal Ikechukwu', Anumudu Christian Kosisochukwu ${ }^{2, ~ *, ~}$ \\ Ihenetu Francis Chukwuebuka ${ }^{1}$, Nwachukwu Innocentia Ogechi ${ }^{1}$, Obasi Chidera Chisom ${ }^{3}$, \\ Ezediunor Caleb Chukwufumnanya ${ }^{2}$
}

${ }^{1}$ Department of Microbiology, Imo State University, Owerri, Nigeria

${ }^{2}$ Department of Microbiology, Federal University, Otuoke, Nigeria

${ }^{3}$ Department of Public Health, Imo State University, Owerri, Nigeria

Email address:

anumuduck@fuotuoke.edu.ng (A. C. Kosisochukwu)

${ }^{*}$ Corresponding author

\section{To cite this article:}

Nwachukwu Micheal Ikechukwu, Anumudu Christian Kosisochukwu, Ihenetu Francis Chukwuebuka, Nwachukwu Innocentia Ogechi, Obasi Chidera Chisom, Ezediunor Caleb Chukwufumnanya. Bacteriological Analysis of Ready-to-Eat Barbecue Meat (Suya) Sold in Yenagoa, Bayelsa State Nigeria. International Journal of Microbiology and Biotechnology. Vol. 4, No. 1, 2019, pp. 24-28. doi: $10.11648 /$ j.ijmb.20190401.15

Received: March 7, 2019; Accepted: April 16, 2019; Published: May 20, 2019

\begin{abstract}
Suya is a traditional barbecued meat product which is produced from deboned meat and spiced up using vegetable oil, various spices, peanut cake, salt and other flavours. It is usually hung on sticks and roasted over an open glowing charcoal fire. It is a popular snack that is sold in the streets of several countries in West Africa. This study was focused on the determination of microbial quality of suya meat sold in Yenagoa, Bayelsa State Nigeria. Five aggregate samples of barbecue (suya) meat were collected from five randomly selected suya vendors in Yenagoa, namely; Berger Junction, Swali Market, Mechanic Junction Amarata, Tombia Roundabout and Opolo Junction. The samples were analysed microbiologically by the pour plate method using various agar media to ascertain the bacteriological diversity and load of the meat and isolates identified via biochemical assays. The bacterial species; Staphylococcus aureus, E. coli, Salmonella spp., Klebsiella spp., Pseudomonas spp. and Shigella spp. were isolated. The total aerobic plate count ranged from Mean Log $4.82-5.30 \mathrm{cfu} / \mathrm{g}$. The result showed that there was no significant difference $(\mathrm{P}<0.05)$ between samples in total aerobic plate count irrespective of the point of collection. Total Coliform Count ranged from Mean Log $4.89-5.45 \mathrm{cfu} / \mathrm{g}$. Sample collected from Amarata had higher Coliform count. The E. coli count ranged from mean Log $5.59-5.96 \mathrm{cfu} / \mathrm{g}$, while Salmonella/Shigella, Staphylococcal counts ranged from Mean Log $4.54-5.99 \mathrm{cfu} / \mathrm{g}$, and $4.55-5.33 \mathrm{cfu} / \mathrm{g}$ respectively. These results show that suya sold in Yenegoa falls below the acceptable standard for human consumption and microbiologically unsafe. The contamination of suya meats may be due to contaminated utensils, use of untreated water and unhygienic manufacturing practices. Hence, there is need for the enforcement of hygienic measures and sensitization of vendors to reduce the microbial load of suya in Yenagoa and minimize the risk of food poisoning.
\end{abstract}

Keywords: Barbecued Meat, Bacterial Load, Coliform

\section{Introduction}

Meat is the flesh of animals which serve as food. It is obtained from sheep, cattle, goat, swine and includes bones, tendons, edible organs and viscera [1]. Traditionally, suya is prepared as barbecued meat hung on sticks and roasted over an open glowing charcoal fire. It is usually spiced with peanut cake, salt and other flavours [2]. It has become very popular as a street delicacy in several countries, particularly those in West Africa [3]. Suya is purely a meat product and is subject to spoilage factors associated with red meat and other meat products. 
Red meat is usually utilized in bologna, suya, patties and several other products. Hence these meat products are prone to quality deterioration if not handled or stored properly. As these microorganisms growing on meat cause textural and organoleptic changes when they release metabolites and are also responsible for food borne illness. They include; Bacillus sp, Clostridium sp, Escherichia coli, Salmonella sp, Shigella sp, Staphylococcus aureus, Streptococcus pyogenes, Proteus, Pseudomonas, Leuconostoc, Lactobacillus sp, Micrococcus, Mycobacterium sp, Vibrio sp etc. Most of these organisms may be transferred from raw meat to cooked meat by hands, surfaces or utensils [4].

There has been reports of sporadic cases in various parts of Nigeria of gastroenteritis after consumption of "Suya", thus indicating the possibility of suya being a food safety risk [5]. However, suya still remain one of the most consumed meat products in Yenagoa. Information available on the quality of suya in Yenagoa is scanty. Therefore the main goal of this study is to investigate the microbial quality of suya meat sold in Yenagoa.

\section{Materials and Method}

\subsection{Sample Collection}

Five samples were collected from each suya vendor by randomly sampling various meat sticks by use of sterile disposable tongs as outlined in process hygiene criteria of Regulation EC 2073/2005 [6] and homogenizing them in a laboratory blender to form an aggregate sample. Aggregate samples were collected from five suya vendors in Yenagoa. Bayelsa State Nigeria located at Berger Junction, Swali market, Mechanic junction Amarata, Tombia roundabout, and Opolo junction, and labelled A-E, respectively. Immediately after collection, the samples were wrapped in sterile aluminum foil to prevent contamination and transported immediately to the laboratory for microbiological analysis.

\subsection{Storage}

Aggregate samples were stored in a refrigerator $\left(5.5^{\circ} \mathrm{C}\right.$ $7.0^{\circ} \mathrm{C}$ ) for two weeks and analysed on days 1, 5 and 9 for total aerobic plate, Coliform, E. coli, Staphylococcus sp., Salmonella sp. and Shigella sp. counts.

\subsection{Sample Pre-treatment}

Pieces of suya were introduced into a laboratory homogenizer. Three grams of the homogenized samples was aseptically introduced into $27 \mathrm{ml}$ of sterile normal saline in a conical flask. The mixture was properly shaken and sieved before $1 \mathrm{ml}$ of the mixture was used for a two-fold serial dilution [7]. For each day of analysis (day 1, 5 and 9), suya samples were withdrawn from the refrigerator and used in preparation of a new stock aliquot for analysis.

\subsection{Culture}

One milliliter aliquot of the diluted sample was dispensed into sterile petri-dishes. $15-20 \mathrm{ml}$ of sterilized molten agar cooled to $45^{\circ} \mathrm{C}$ was added to each plate. The plates were inverted and incubated at $37^{\circ} \mathrm{C}$ for 24 hours [8]. Total viable count, coliform count, Salmonella/Shigella count, E. coli count and Staphylococcal count were determined first by culturing on Nutrient agar, MacConkey Agar, Salmonella/Shigella Agar, Eosin Methylene Blue Agar and Mannitol Salt Agar, respectively using the plate count method, followed by colony counting with the aid of a colony counter according to the method described in [9].

Colonial morphology of developed colonies was noted and counted. Discrete colonies were purified by subculturing onto nutrient agar plates. Isolated bacterial species were identified by subjecting them to various biochemical tests including; coagulase, catalase, oxidase, motility tests, starch, glucose, sucrose and lactose fermentation [10].

\subsection{Statistical Analysis}

The data were subjected to analysis of variance. Duncan multiple range and $\mathrm{F}$ test were used to separate the means.

\section{Results}

\subsection{Total Aerobic Count}

The total aerobic plate reported in suya meat samples was within acceptable range after nine days of refrigerated storage. Meat with total aerobic plate count of mean Log 7.00 $\mathrm{cfu} / \mathrm{g}$ gives off flavor, while at mean $\log 8.00 \mathrm{cfu} / \mathrm{g}$, it is regarded as unacceptable for consumption [11]. The results are presented graphically in Figure 1 below.

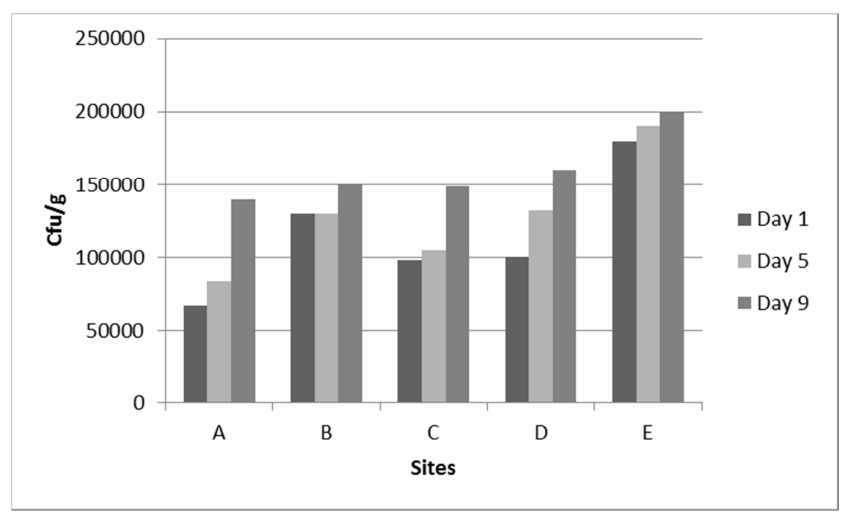

Figure 1. Total aerobic plate count following storage at refrigerated temperature of $5.5-7.0^{\circ} \mathrm{C}$ for 9 days.

Keys

$A=$ Berger junction

$\mathrm{B}=$ Swali market

$\mathrm{C}=$ Mechanic junction Amarata

$\mathrm{D}=$ Tombia roundabout

$\mathrm{E}=$ Opolo junction 


\subsection{Total Coliform Count}

The total coliform count ranged from $4.89-5.45 \mathrm{cfu} / \mathrm{g}$ during the nine days of storage of the meat sample at refrigerated temperature and is presented graphically in Figure 2 below.

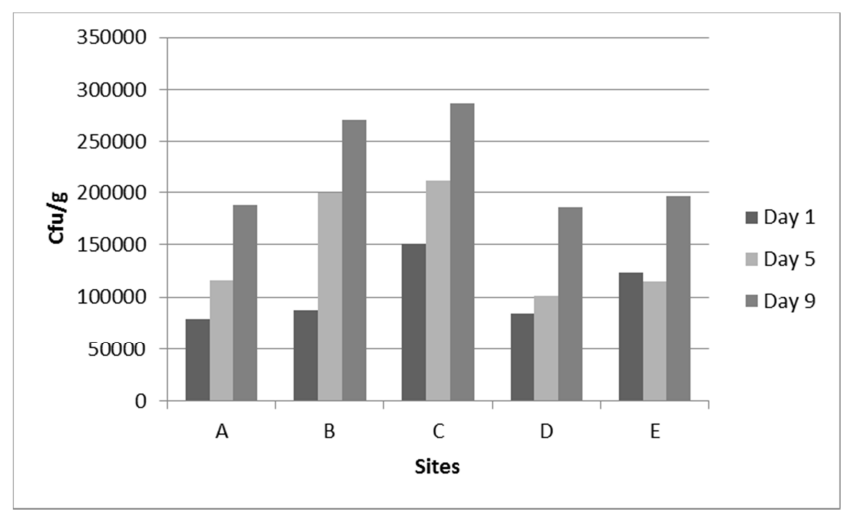

Figure 2. Coliform count following storage at refrigerated temperature of $5.5-7.0^{\circ} \mathrm{C}$ for 9 days.

Keys

$A=$ Berger junction

$\mathrm{B}=$ Swali market

$\mathrm{C}=$ Mechanic junction Amarata

$\mathrm{D}=$ Tombia roundabout

$\mathrm{E}=$ Opolo junction

\subsection{Total E. coli Count}

The Mean Log values of E. coli count ranged from 5.59 to $5.83 \mathrm{cfu} / \mathrm{g}$ as presented in Figure 3.

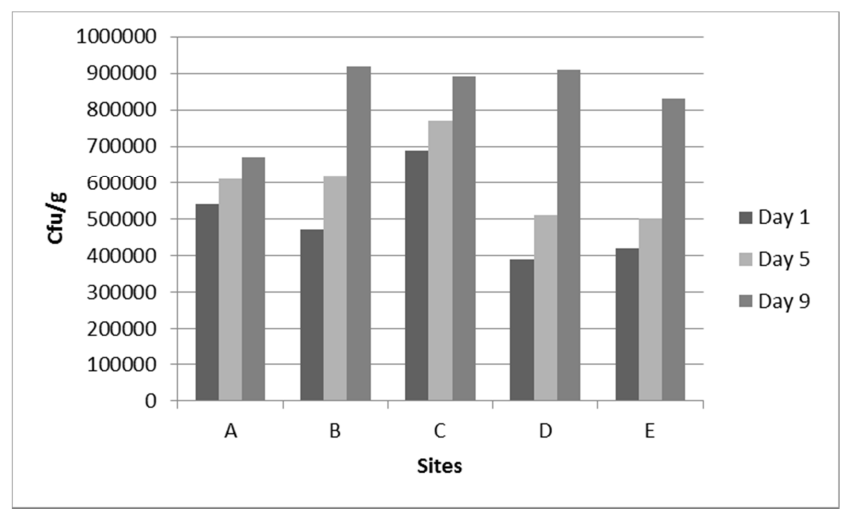

Figure 3. E. coli count following storage at refrigerated temperature of $5.5-$ $7.0^{\circ} \mathrm{C}$ for 9 days.

Keys

$A=$ Berger junction

$\mathrm{B}=$ Swali market

$\mathrm{C}=$ Mechanic junction Amarata

$\mathrm{D}=$ Tombia roundabout

$\mathrm{E}=$ Opolo junction

\subsection{Total Salmonella/Shigella Count}

The total Salmonella - Shigella count ranged from 4.54 to $5.99 \mathrm{cfu} / \mathrm{g}$, throughout the nine days of storage as presented in Figure 4 below.

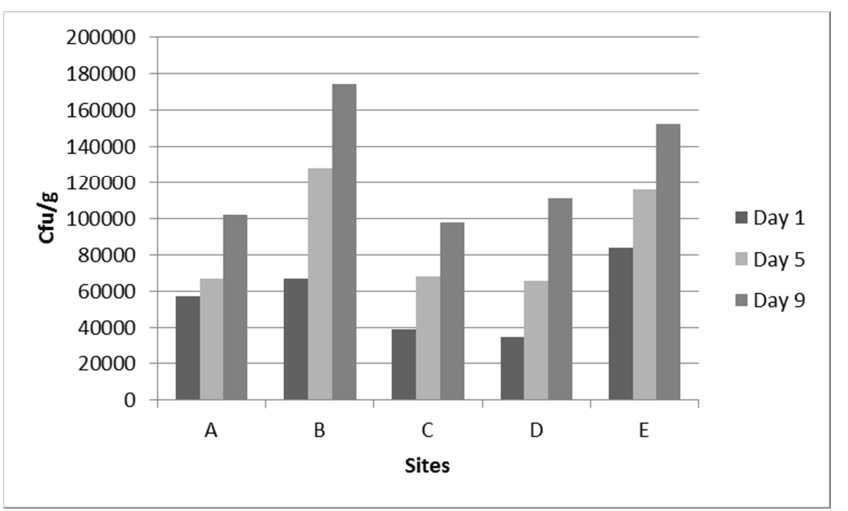

Figure 4. Total Salmonella/Shigella count following storage at refrigerated temperature of $5.5-7.0^{\circ} \mathrm{C}$ for 9 days.

Keys

$A=$ Berger junction

$\mathrm{B}=$ Swali market

$\mathrm{C}=$ Mechanic junction Amarata

$\mathrm{D}=$ Tombia roundabout

$\mathrm{E}=$ Opolo junction

\subsection{Total Staphylococcal Count}

The Staphylococcal load ranged from 4.49 to $5.33 \mathrm{cfu} / \mathrm{g}$ and is presented graphically in Figure 5 below.

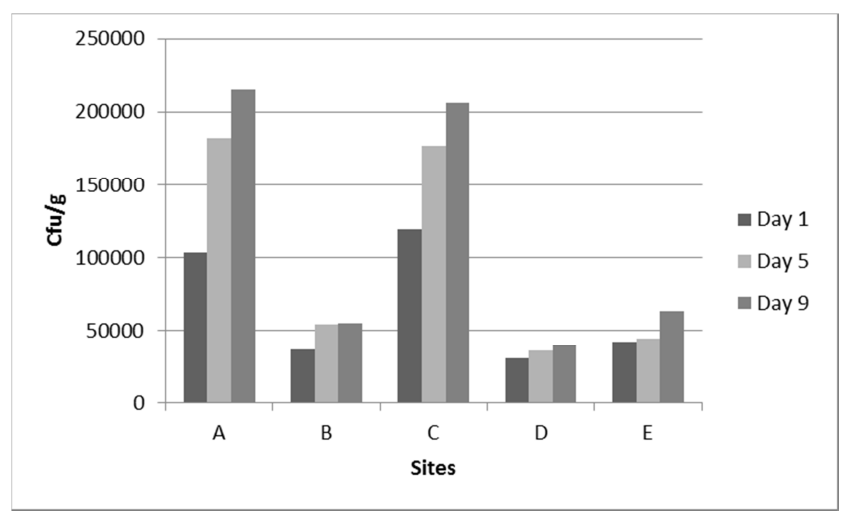

Figure 5. Staphylococcal count following storage at refrigerated temperature of $5.5-7.0^{\circ} \mathrm{C}$ for 9 days.

Keys

$\mathrm{A}=$ Berger junction

$\mathrm{B}=$ Swali market

$\mathrm{C}=$ Mechanic junction Amarata

$\mathrm{D}=$ Tombia roundabout

$\mathrm{E}=$ Opolo junction

\subsection{Biochemical Characterization of the Isolated Organisms}

For identification of isolated organisms, biochemical tests including; coagulase, catalase, oxidase, motility tests, starch, glucose, sucrose and lactose fermentation were undertaken. Seven bacteria species were isolated including; E. coli, Pseudomonas, Staphylococcus aureus, Salmonella, Shigella and Klebsiella. 
Table1. Summary of Microorganisms isolated from different locations in Yenegoa.

\begin{tabular}{ll}
\hline Location & Organism \\
\hline Berger Junction & Staphylococcus aureus \\
Swali Market & Staphylococcus aureus \\
& Salmonella \\
Mechanic Junction, Amarata & E. coli \\
& Klebsiella \\
& Salmonella \\
Tombia Roundabout & Pseudomonas \\
& Staphylococcus aureus \\
Opolo Junction & E. coli \\
& Klebsiella \\
& Salmonella \\
\hline
\end{tabular}

\section{Discussion}

The total microbial load obtained from all samples ranged from mean $\log 4.82$ to $5.25 \mathrm{cfu} / \mathrm{g}$ on day 1 and the value were not significantly different $(\mathrm{p}>0.05)$ irrespective of the point of collection. After 9 days of storage at refrigeration temperature, the values ranged from mean $\log 5.14$ $5.30 \mathrm{cfu} / \mathrm{g}$. The values on day 1 were lower than mean $\log$ values of $4.81-7.27 \mathrm{cfu} / \mathrm{g}$ which was reported for retailed suya samples in Makurdi by [12]. The values were also lower than the mean $\log$ of $6.30-6.46 \mathrm{cfu} / \mathrm{g}$ reported for suya meat products in Bauchi by [13]. However, these values were higher than $1.40-2.22 \mathrm{cfu} / \mathrm{g}$ reported by [14] in South - West Nigeria. The differences in values may be due to the method of preparation, cuts of meat, heat applied and the varying weather condition at the point of sampling. The total aerobic colony count recorded for suya retailed in Yenegoa Bayelsa state is higher than the maximum permissible limit of Log $5.0 \mathrm{cfu} / \mathrm{g}$ as set by EC regulation 2073/2005 [6], thus indicating their unacceptability and possible negative health consequences of their consumption.

The total coliform count ranged from $4.89-5.45 \mathrm{cfu} / \mathrm{g}$ during the nine days of storage of the meat sample at refrigeration temperature. The values were slightly higher than mean $\log$ values $2.23-4.32 \mathrm{cfu} / \mathrm{g}$ reported for similar products in Makurdi [12]. The presence of coliform suggests that the suya samples were prepared under unhygienic condition, indicating feacal contamination. The high number of coliforms recorded in this study is worrisome because of the possibility of contamination from other microorganisms of feacal origin. Coliforms are indicator organism and is therefore used to assess the presence of other contaminants. Higher coliform values were obtained in the sample collected from Mechanic Junction, Amarata when compared to those obtained from Swali Market, Berger Junction and Tombia Roundabout. After about nine days of storage at refrigerated temperature, there was little or no difference $(p<0.05)$ in values in coliform count, irrespective of the point of collection. EC regulation 2073/2005 outlined a maximum coliform count of $\log 2.5 \mathrm{cfu} / \mathrm{g}$ for Enterobacteriaceae. Thus, values above this indicates possible feacal contamination by coliforms.

The Mean Log values of E. coli count ranged from 5.59 to
$5.83 \mathrm{cfu} / \mathrm{g}$ on day one. After nine days of storage at refrigeration temperature, the mean $E$. coli count ranged from mean $\log 5.82$ to $5.96 \mathrm{cfu} / \mathrm{g}$. EC Regulation 2073/2005 stipulates E. coli counts less than $5 \times 10^{3} \mathrm{cfu} / \mathrm{g}$ for meat preparations. The sample collected from Tombia Roundabout had the lowest $E$. coli count $(\mathrm{P}<0.05)$ when compared to the sample collected from Amarata which had the highest E. coli count on day one. After nine days, there was little or no difference in the mean $\log E$. coli count. The high bacterial load of $E$. coli could be a problem as they have been implicated in food poisoning especially in the young and elderly and is associated with travelers' diarrhea.

The total Salmonella - Shigella count ranged from 4.54 to $5.99 \mathrm{cfu} / \mathrm{g}$, throughout the nine days of storage. Suya samples collected from Mechanic Junction, Amarata have the lowest number of Salmonella and Shigella, while sample collected from Opolo Junction had the highest number. Salmonella and Shigella are both found in the gut and have been associated with acute bacterial diarrhea and food poisoning and are not acceptable in meat and meat products [6]. These organisms may have come from herbs and spices used in the preparation of suya. Furthermore, enteric bacteria and Salmonella species have been detected in spices that were improperly preserved [11]. Thus, this may be the source of contamination of the assayed suya.

The Staphylococcal load ranges from 4.49 to $5.33 \mathrm{cfu} / \mathrm{g}$. The high level of Staphylococcus species may be as a result of lack of personal hygiene of the processors, from dust and lack of good handling and manufacturing practices. Samples collected from Tombia Roundabout had the lowest Staphylococcal population while sample collected from Berger Junction had the largest Staphylococcal population.

\section{Conclusion}

Retailed suya meat products sold in Yenagoa are contaminated with bacteria and have total aerobic plate count which ranged from mean Log $4.82-5.33 \mathrm{cfu} / \mathrm{g}$. Although microbial load was not excessive, the presence of pathogenic bacteria in these meat products is unacceptable. Contamination of the retail suya meat product sold in Yenagoa is possibly due to poor hygienic practices which led to cross contamination, the use of utensils that were not properly washed, untreated water, poor manufacturing practices and improper application of heat. Retailed suya in Yenegoa, Bayelsa State Nigeria fell short of the European Commission regulations on microbiological criteria for meat and meat products with high coliform, E. coli and Salmonella/Shigella counts, thus indicating this class of ready-to-eat meat as a potential source of harmful bacteria to consumers with attendant public health consequences. Although suya assessed in this work was stored in the refrigerator, it was observed that there was a higher bacterial count after 9 days of storage. This implies that many of the bacterial contaminants of suya are able to survive refrigeration temperatures and proliferate probably due to the original high microbial load of the suya product, the moisture 
content and substantial nutrient contents of suya which is able to meet all the growth requirements of the organisms.

Good manufacturing practices is necessary for the production of suya products. It is recommended that suya vendors should be taught good hygiene practices in order to keep their product safe from microbial contamination. These products should not be exposed to dust in the environment. Furthermore, appropriate packaging materials and sufficient heat should be applied to eliminate presence of bacteria in the raw meat.

\section{Acknowledgements}

Authors acknowledge with thanks technical staff of the Federal University Otuoke, Bayelsa State and Imo State University Owerri all in Nigeria for their technical support and for supplying most of the reagents used.

\section{References}

[1] Forrest, J. C., Aberle, E. D., Gerrard, D. E., Mills, W. E., Hedrick, H. B., Judge, M. D. and Merkel, R. A. (2001). The Principles of Meat Science. Kendall/Hunt Publishing Company: U.S. 4th Edition.

[2] Abdullahi, I. O, Umoh, V. J, Ameh, J. B. and Galadima, M. (2004): Hazards associated with kilishi preparation in Zaria, Nigeria. Nigerian Journal of Microbiology. 18 (1-2) Pp. 339345 .

[3] Inyang, C. U., Igyor, M. A. and Uma, E. N. (2005). Bacterial Quality of a Smoked Meat product ('Suya'). Nig. Food J. 23: 239-242.

[4] Kigigha, L. T., Ovunda, H. O. and Izah, S. C. (2015). Microbiological quality assessment of suya sold in Yenegoa Metropolis, Nigeria. Journal of Advances in Biological and Basic Research. 1 (5): 105-109.
[5] Odusote, K. A and Akinyanju, O. O. (2003) Microbiological evaluation of Suya sold in Ado and Akure, South West Nigeria. Consumer Safety Bulletin, 2: 20-24.

[6] Codex (2005): Commission Regulation (EC) No. 2073/2005 on Microbiological criteria for foodstuffs. Official Journal of the European Union. L 338: 1-26.

[7] AOAC (2004): Association of Analytical Chemist, Official Methods of Analysis, 17th ed. Maryland Ch 45, 112-120.

[8] Falegan, C. R., Akoja, S. O. and Oyarekua, M. A. (2017). Microbiological assessment of suya (sliced roasted beef) in Ado-Ekiti Metropolis, Ekiti State, Nigeria. MOJ Biol Med. 2 (3): 266-269.

[9] Goldman, E. and Green, L. H. (2008). Practical Handbook of Microbiology ( $2^{\text {nd }}$ ed.). USA: CRC Press, Taylor and Francis Group. p. 864.

[10] Harrigan, W. F. (2000). Laboratory Methods in Food Microbiology. 3rd Ed. Academic Press, London. 186-189.

[11] Willey, J. M., Sherood, L. M. and Christopher, J. W. (2011). Prescott's Microbiology. Eight ed. McGraw Hill Company Inc., 1221 Avenue of the Americas, New York.

[12] Manyi, M. M., Idu, F. I. and Ogbonna, I. O. (2014). Microbiological and parasitic quality of suya (roasted beef) sold in Makurdi, Benue State, Nigeria. Africa Journal of Microbiology Research. 8 (35): 3235-3242.

[13] Moshood, A. Y., Abdul, T. H. T., Abdul, H. and Ibrahim, H. (2012). Isolation and Identification of Bacteria Associated with Balangu (Roasted Meat Product) Sold in Bauchi. Nigeria. IOSR Journal of Pharmacy: 2250-3013.

[14] Edema, M. O., Osho, A. T. and Diala, C. I. (2008). Evaluation of microbial hazards associated with the processing of Suya (a grilled meat product). Scientific Research and Essay. 3 (12): 621- 626 . 